\title{
Tarde o temprano
}

\author{
Sooner or later
}

$\mathrm{C}$ on cierta frecuencia a los pediatras se nos pregunta hasta qué edad atendemos a los niños, sobre todo cuando estos se aproximan a la adolescencia.

Hace más o menos 10 años entró a mi oficina un matrimonio campesino con su hijo, un chiquillo bastante corpulento. La madre antes de sentarse me pregunta:

- Doctor, ¿hasta qué edad atiende usté a los niños? porque no sé si él está pa' que lo atienda usté.

- Señora -le respondí con cierta picardía- yo atiendo a los niños desde su primera diarrea hasta la primera gonorrea.

Yo pensé que mi respuesta sería motivo de risa, como siempre había ocurrido en otras ocasiones. Sin embargo, esta vez sucedió lo contrario, y el padre muy serio acotó:

- No faltaba más. Yo te lo había alvertio Irene que este cabro capaz que esté pringao.

- ¿Qué le pasa?- pregunté poniéndome serio.

- Mire doctor -dijo Irene- últimamente ha andao medio enamorao, pero que le explique su padre mejor.

- A ver, muéstrale al doctor lo que tení.

El chiquillo medio avergonzado se descubre y me muestra sus genitales dejando escurrir una secreción purulenta por el meato. Acto seguido les digo:

- Me temo que esta va a ser la última visita al pediatra porque lo que su hijo tiene es una gonorrea.

Desde aquella vez pongo más cuidado antes de responder hasta qué edad atendemos los pediatras; sin embargo, esta ha sido la única gonorrea que he atendido en 25 años de práctica pediátrica.

Enzo Tassara P. etassara1@gmail.com Hospital Clínico Herminda Martín Chillán, Chile

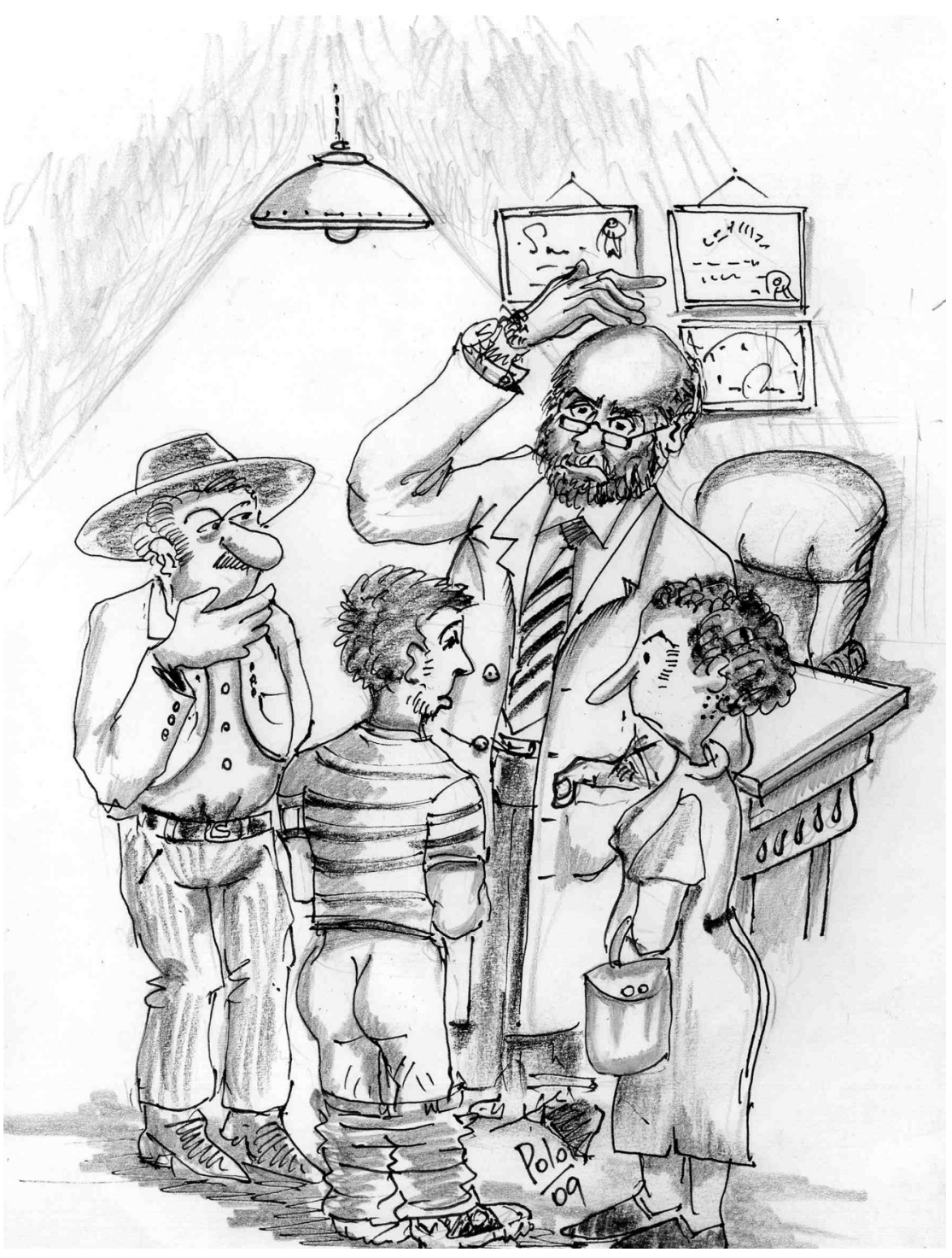

